\title{
Correction: Cancer-related mortality in Peru: Trends from 2003 to 2016
}

\section{The PLOS ONE Staff}

The fourth author's name is spelled incorrectly. The correct name is: Rodrigo M. CarrilloLarco. The correct citation is: Zafra-Tanaka JH, Tenorio-Mucha J, Villarreal-Zegarra D, Carrillo-Larco RM, Bernabe-Ortiz A (2020) Cancer-related mortality in Peru: Trends from 2003 to 2016. PLoS ONE 15(2): e0228867. https://doi.org/10.1371/journal.pone.0228867

The publisher apologizes for the error.

\section{Reference}

1. Zafra-Tanaka JH, Tenorio-Mucha J, Villarreal-Zegarra D, Carrillo-Larco R, Bernabe-Ortiz A (2020) Cancer-related mortality in Peru: Trends from 2003 to 2016. PLoS ONE 15(2): e0228867. https://doi.org/ 10.1371/journal.pone.0228867 PMID: 32027719

\section{Gopenaccess}

Citation: The PLOS ONE Staff (2020) Correction: Cancer-related mortality in Peru: Trends from 2003 to 2016. PLoS ONE 15(3): e0230271. https://doi. org/10.1371/journal.pone.0230271

\section{Published: March 4, 2020}

Copyright: ๑ 2020 The PLOS ONE Staff. This is an open access article distributed under the terms of the Creative Commons Attribution License, which permits unrestricted use, distribution, and reproduction in any medium, provided the original author and source are credited. 